\title{
Reading as Re-reading: The Poetic Function of the Grammatical Ambiguity in Jer 51:20-24
}

\author{
ŁUKASZ POPKO OP \\ École Biblique et Archéologique Française de Jérusalem \\ e-mail: lukasz.popko@dominikanie.pl \\ ORCID: 0000-0003-0546-8692
}

\begin{abstract}
Summary: The grammatical ambiguity of Jer 51:20-24 results in three possible interpretations: 1) Babylon as God's weapon; 2) an announcement of Babylon's demise; 3) God as the victorious ruler of the world history. The ambiguity should be considered as a poetic trope.
\end{abstract}

KEY WORDS: grammatical ambiguity; Jer 51:20-24; Babylon; hermeneutics

\section{Hammerspruch}

A short and rarely commented on poem on the club of God, the Hammerspruch in Jer 51:20-24, is grammatically ambiguous. The vocabulary of the passage is unproblematic, the grammatical forms regular, and the context clear, yet modern translations are not satisfactory. Although all the verses are constituted by a series of weqatalti verbs, v. 20-23 are often interpreted as referring to the past and v. 24 to the future. ${ }^{1}$ Some commentators avoid the problem, regrettably applying the present tense throughout, but still assuming an adversative waw in v. 24. ${ }^{2}$ The fact is, however, that the grammatical interpretation depends on the identity of the metaphoric club of God. While scholars feel obliged to choose

1 See for example: Bible de Jérusalem (1998), New Jerusalem Bible, Bibbia della Conferenza Episcopale Italiana, Biblia Tysiaclecia. A similar shift is suggested also by Traduction Ecuménique de la Bible and Einheitsübersetzung.

2 A. Condamin, Le livre de Jérémie. Traduction et commentaire (troisième édition corrigée) (EB 14; Paris: Librairie Lecoffre: J. Gabalda et Compagnie 1936) 342; J. Bright, Jeremiah. Introduction, Translation and Notes (AB 21; New York: Doubleday 1965) 356; J.R. Lundbom, Jeremiah 37-52: A New Translation with Introduction and Commentary (AB 21C; New York: Doubleday 2004) 451; Revised Standard Version; New Revised Standard Version; W. McKane, Critical and Exegetical Commentary on Jeremiah. 2. Commentary on Jeremiah XXVI-LII (ICC; Edinburgh: T\&T Clark 1996) 1310 (McKane rendered all the verbs in the future tense). 
among the possibilities, Yair Hoffman has briefly noted that this poem remains irreversibly equivocal. ${ }^{3}$ My contention is that we do not have to choose only one interpretation because it is precisely the interpretative ambiguity of the poem that should be noted, followed, and understood.

A single English translation is not able to render Jer 51:20-24 without losing this feature of the original Hebrew text. The three subsequent translations proposed in this article intend to express it more clearly, but also to trace the interpretative process, in which the reader - while construing a meaningful context - radically modifies his interpretation. The subsequent interpretations follow the questions arising from the progressively broadening context. The Hammerspruch will be interpreted as 1) a poem about Babylon as God's weapon from the past; 2) a future judgment on Babylon; 3) an oracle with a metahistorical perspective. At the end, some hermeneutic conclusions will be suggested.

\section{Ambiguity}

It is probably possible to study this text from a diachronic perspective and trace the ways in which the subsequent authors or redactors reshaped an original poem. Nevertheless, even if the present ambiguities were created by an accumulative growth, the last editor must have been aware that the final form is equivocal, lest unreasonably we think that the ancient authors were mindless. Since the MT is sufficient to illustrate the literary function of ambiguity, my analysis will be limited to this synchronic perspective.

Ambiguity is a broadly discussed issue in logic and is an inherent feature of human language as such. For the New Criticism ambiguity is a fundamental quality of all literature and in particular of poetry. ${ }^{4}$ Nevertheless, in the case of our poem one is able to be more precise and define this ambiguity as a case of amphiboly, i.e. "the grammatical structure of a sentence exhibiting multiple (grammatical) sentence structures that give it different meanings". ${ }^{5}$ From the perspective of rhetoric, ambiguity is a fault, yet, from the perspective of a poet it is rather a tactic.

3 Y. Hoffman, "Jeremiah 50-51 and the Concept of Evil in the Hebrew Bible", The Problem of Evil and Its Symbols in Jewish and Christian Tradition (ed. H.G. Reventlow - Y. Hoffman) (JSOT.S 366; London: A\&C Black 2004) 23-24. For some review of the XX c. scholarly discussion see: McKane, Jeremiah. 2, 1310-1312.

4 See especially the very influential book by William Empson, Seven Types of Ambiguity; first published in 1930 and since republished many times.

5 For a broader horizon on the matter see e.g.: D. Walton, Fallacies Arising from Ambiguity (Applied Logic Series 1; Springer Science \& Business Media 2013) 77. The definition follows largely the traditional definition by Aristotle in De Sophisticis Elenchis (165 b). 
It is very telling that in the Greek literature, it is precisely the prophetic oracles which served as a common scholarly illustration of ambiguity. Aristotle spoke about the equivocal oracles which intended to deceive their listeners, especially by the means of their vagueness; its intention was to reduce the possible impression of the failed prophecy. ${ }^{6}$ Plutarch, both a philosopher and a priest at Delphi, wrote a whole treatise on the theme of the literary form of the oracles which at his time (I c. AD) became less frequent but also more prosaic and unequivocal (De defectu oraculorum). He explains the ambiguous character of the oracles of old as a divine tactics:

Men ought to understand thoroughly, as Sophocles says, that the god is:

'For wise men author of dark edicts aye,

For dull men a poor teacher, if concise'?

According to Plutarch, such a mysterious form inspired awe but sometimes also protected god's servants against the wicked people and tyrants. ${ }^{8}$ The ambiguity of the oracles is an attested preoccupation of the receivers of the ancient Near Eastern prophecies and this aspect can be traced also in the books of the Hebrew Bible. ${ }^{9}$ The ambiguity traced in Jer 52 should not be therefore perceived as an imperfection of style.

I will argue that in the Hammerspruch ambiguities do not produce just vagueness or indeterminacy, on the contrary, they guide the reader through precise and not fortuitous paths. This is precisely their aim: to set the reader in motion, compelling him to reread, reinterpret, and re-contextualise the poem.

6 The temporal vagueness also serves to preserve the presumed veracity of the oracle. See: Aristotle, Rhet. 3.1407ab. The philosopher refers to the famous Delphic oracle announced to Croesus as quoted by Herodotus, Hist., 1,53. In his book on ambiguity Walton refers to the same prophetic case (Walton, Fallacies, 93). In Poetics (25, 1461a) Aristotle speaks about the ambiguity which should be resolved by a correct punctuation. A more recent rhetor Sopatros also illustrated the amphibole by an ambiguous oracle taken from Herodotus, Hist., 7,141: "Wide-seeing Zeus gives wooden walls to Athena". See: D.A. Russell, Greek Declamation (Cambridge UK: Cambridge University Press 1983) 70.

7 Plutarch, De pythiae oraculis, 407, Moralia. 5. (transl. F. C. Babbitt) (Loeb Classical Library 306; Cambridge: Harvard University Press 1969) 329.

8 "There were naturally some things which it was well that despots should fail to understand and enemies should not learn beforehand. About these, therefore, he put a cloak of intimations (hyponoias) and ambiguities (amphilogias) which concealed the communication so far as others were concerned, but did not escape the persons involved nor mislead those that had need to know and who gave mind to the matter"; ibid., 333-335.

9 J.J.M. Roberts, "Does God Lie? Divine Deceit as a Theological Problem in Israelite Prophetic Literature", in: John A. Emerton (ed.), Congress Volume - Jerusalem 1986 (VT.S, 40; Leiden: Brill 1988) 211-220; and Ł. Popko, "פי־שנים in 2 Kgs 2:13 as a Metaphor of Double Speech", $R B$, forthcoming. 


\section{V. 20-23: Babylon as God's weapon}

Of all oracles against the nations in the book of Jeremiah, Jer 50-51 with its judgement on Babylon is the longest and the most developed composition. The few verses of Jer 51:20-23 are compact and repetitive, like the strikes of a club, which serves as its main motif. It is hardly surprising that the reader spontaneously refers the text to Babylon, the enemy par excellence of Jerusalem. Since already in Jer 50:23 we have read about Babylon the "hammer of all the earth," which has been cut off and broken, the first reading results in the following understanding of this text:

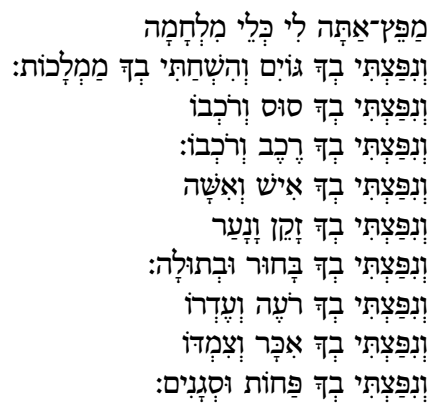

A club you were to me, ${ }^{10}$ an instrument of war!

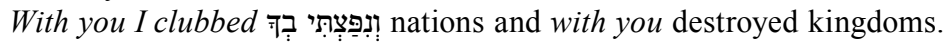

With you I clubbed horse and its rider,

With you I clubbed chariot and its charioteer.

With you I clubbed man and woman,

With you I clubbed old and young,

With you I clubbed lad and maiden.

With you I clubbed shepherd and his flock,

With you I clubbed farmer and his team,

With you I clubbed governors and prefects (51:20-23).

The material meaning of the Hebrew מַפ has generated some scholarly discussion. Is this a weapon per se or just any instrument, like a hammer, which only secondarily could be used in battles? For our analysis it is enough to note

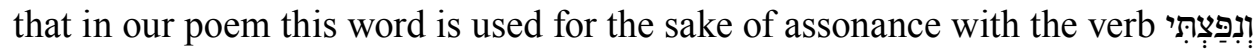
which is based on the same root נפץ 'to shatter,' 'to dash.' The translation applied here ("to club with a club" ${ }^{\text {") }}$ ) attempts to preserve this figura etymologica.

10 See a similar construction in Jer 22:6 "[like] Gilead you are to me".

11 The same: M. Kessler, Battle of the Gods: The God of Israel versus Marduk of Babylon: A Literary/Theological Interpretation of Jeremiah 50-51 (SSN 42; Assen 2003) 117. 
One can propose other solutions with a certain licentia poetica: 'to shatter with a shatterer' or 'to dash with a dasher', etc.

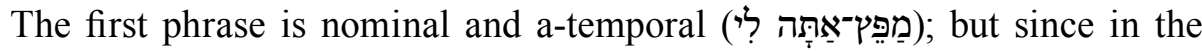
reader's pre-understanding this is a poem about Babylon's demise, the past reality as its context is self-imposing. The following finite verb וְנִפְּצִתִ 'I clubbed' is repeated nine times and, along with the only other verb in these verses ('and

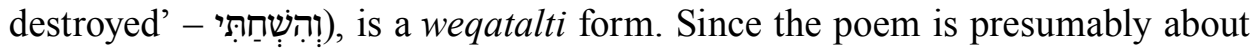
the past function of Babylon, weqatalti verbs are therefore understood as inverted perfects: referring to the past and expressing the aspect of a repeated action ${ }^{12}$ : 'I used to club', 'I clubbed over and over'.

Accordingly, the prepositional phrase בִ must be understood here as expressing an instrumental function. Not only does the presumed function of Babylon suggest this meaning, but also the above-mentioned paronomastic phrase 'to

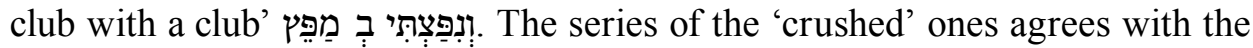
image of Babylon as an empire at the service of God. This divine weapon has an international range ('nations', 'kingdoms'), appears in the military context ('horses and chariots'), and touches all social layers.

\section{V. 20-24a: Future Destruction in Babylon}

This initial, straightforward and coherent interpretation breaks down when the reader arrives at v. $24 \mathrm{a}$, which continues the preceding lines with the same

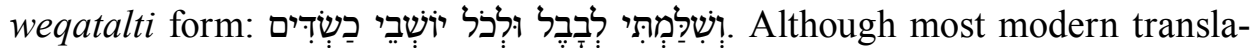
tions introduce an adversative conjunction at this point, ${ }^{13}$ nothing of this kind exists in the Hebrew text. Based solely upon the grammar and vocabulary, there is nothing that might suggest a reversal or an opposition. In fact, the only reversal takes place in the head of the reader, who is forced to revise his first understanding. If one continues to interpret the weqatalti verbs as referring to past, repeated events, v. 24a should be understood: "I repaid Babylon (again and again) and all the inhabitants of Chaldea." Since this interpretation is improbable, the reader reinterprets the verbal form (as some commentators do) ${ }^{14}$ as relating to future events: "I shall repay Babylon, and all the inhabitants of Chaldea."

12 P. Joüon - T. Muraoka, A Grammar of Biblical Hebrew (revised edition) (SubBib 27; Roma: Pontificio Istituto Biblico 2006) $§ 119 u$.

13 Besides the translations mentioned in $\mathrm{n} .1$ and 2 we may add here also Kessler, Battle, 118, and G. Fischer, Jeremia 26-52 (HThKAT; Freiburg i.B.: Herder Verlag 2005) 609.

14 A.B. Ehrlich, Randglossen zur Hebräischen Bibel. 4. Jesaia, Jeremia (Leipzig: J.C. Hinrichs 1912) 369. For similar interpretations of R.P. Carroll and E. W. Nicholson see further in n. 19 and 23 . 
In consequence, since this is exactly the same grammatical form as in all the preceding verses, v. 24 forces us to reread v. 20-23 and this time to interpret them as referring to the future:

A club you were against me, an instrument of war,

And (therefore) in you I will club nations and in you I will destroy kingdoms.

In you I will club horse and its rider,

In you I will club chariot and its charioteer.

In you I will club man and woman,

In you I will club old and young,

In you I will club lad and maiden.

In you I will club shepherd and his flock,

In you I will club farmer and his team,

In you I will club governors and prefects.

In you I will pay Babel and all the inhabitants of Chaldea for all their evil which they have done in Zion.

$(51: 20-24 a)$

The weqatalti verbs are here understood as future subsequent actions or even express consecution. ${ }^{15}$ This is, incidentally, also one of the oldest interpretations, as the LXX and Vulgate prove: $\delta \iota \alpha \sigma \kappa O \varrho \pi \mathrm{\omega} \tilde{\omega}$, conlidam.

The reinterpretation of the verbal forms brings in its train a reinterpretation of other phrases. Setting the poem in the future demands understanding $\underset{?}{\dddot{y}}$ as a beth locativum and not in an instrumental sense. It is also possible now to construe בְ as an adversative 'against you.' The presence of the nations and kingdoms endangered "in Babel" may surprise a bit, but this broad perspective agrees with the general rhetoric of Jer 51. The two last objects of crushing, are of Akkadian origin, which plausibly suggests Babylonian officials. ${ }^{16}$ In fact, further on in v. 57 we will find the same word pair clearly identifiable as the fallen executives of Babylon. The entire populace is called upon to flee from the midst of Babylon to save their lives (51:6). This corresponds to the earlier announcements, also in weqatalti: "And they will fall down slain $\underset{?}{\text { in }}$ in the land of the Chaldeans, and pierced through $\underset{?}{\text { in }}$ in her streets" (51:4). The preposition י? in v. 20a may further gain the value of a dative of disadvantage: "You were a club against me, therefore I will club".

The twofold meaning of the verbal forms was noted already by Carl Friedrich Keil. For him this temporal ambiguity means that when the Hammerspruch was written Babylon was still an active power:

Finally, the employment of the perfect with waw relative, both in connection with the shattering to pieces which God accomplishes with (by means of) Babylon, and also the

15 Joüon - Muraoka, Grammar, §119cde.

16 Fischer, Jeremia 26-52, 609. 
retribution He will execute on Babylon, is explained by the fact, that just as, in prophetic vision, what Babylon does to the nations, and what happens to it, was not separated into two acts, distinct from one another, but appeared as one continuous whole, so also the work of Babylon as the instrument of destruction was not yet finished, but had only begun, and still continuing, was partly future, like the retribution which it was to receive for its offence against Zion; just as in v. 13 Babylon is viewed as then still in the active exercise of power; and the purpose for which God employs it, as well as the fate that is to befall it, is presented together in something like this manner: "O Babylon, who art my hammer with which I break peoples and kingdoms in pieces, thee will I requite!" 17

Keil's intuition is indeed valuable, for it suggests that the poem consciously plays on the temporal perspective: the very same verses speak about Babylon as God's club and announce her destruction. The ambiguity of the poem is therefore anything but accidental. It expresses the inevitability of ius talionis through its very literary form in which crime and punishment are verbally inseparable and suggest a quasi-logical necessity. To club and to be clubbed in the future are distinguishable only through a mental differentiation.

The exercise of producing two English translations, one in the past and once in the future tense, may create an impression for modern readers that the Hebrew weqatalti verbs hide two homonymous forms. And yet, for the reader of the original text this distinction between the past and the future does not have to present itself as an opposition. וٕנַפְּצִתי speaks about the past, therefore it speaks also about the future. The new meaning of the poem builds on and presupposes the first one. The reinterpretation does not mean considering the first interpretation as a mistake. On the contrary, understanding that the poem is at the same moment about the past and about the future is essential for grasping its intention. Grammatical options set the reader's mind on the way, oblige him gradually to broaden the context and to reread it again and again. Possible interpretations are only seemingly contradictory; they are not indiscriminate or arbitrary, rather the poem itself provides the clues for the reinterpretation.

\section{V. 20-24: Who is God's Instrument?}

According to the first interpretation, God clubbed with Babylon. ${ }^{18}$ The second reading convinces us also that God will club in Babylon. Until now, I have

17 C.F. Keil, Commentary in the Old Testament. 8. Jeremiah, Lamentations (originally Edinburgh 1866-1891) (Peabody, MA: Hendrickson Publishers 2006) 442.

18 Most of the XX c. commentators remained with the interpretation of Babylon as the divine mace (P. Volz, Der Prophet Jeremia (Zweite Aufl.) (KAT 10; Leipzig: A. Deichertsche Verlagsbuchhandlung D. Werner Scholl 1928) 432; A. Condamin, Le livre de Jérémie. Traduction et commentaire (troisième édition corrigée) (EB 14; Paris: Librairie Lecoffre: J. Gabalda et 
purposefully avoided v. 24 , which in the present form of the text serves as the poem's conclusion and broadens the interpretative horizon once again. V. 24 does not continue the anaphora of the poem; yet, the "oracle of YHWH" formula at its end rounds up the whole passage; therefore v. 24 constitutes its essential part. The direct address to the weapon in v. 20 (2 אָתָה m.s.) corresponds to the phrase "before your eyes" in the last phrase of v. 24: "And I will repay Babylon and all the inhabitants of Chaldea for all their evil which they have done in Zion before your eyes" (2 לְעינֶיכו m.pl.). The difference between the singular form in v. 20 and the plural in v. 24 weakens the probability that the two addressees are identical but it does not have to hinder this interpretation.

In Jer 51 the usual addressee of the oracles is Babylon herself, but since in v. 24 she is spoken of and not spoken to, the identity of the addressee becomes open for a different interpretation. Who will be God's club this time? A broader context allows the possibility of yet another, third translation:

A club you will be to me, an instrument of war!

With you I will club nations and with you I will destroy kingdoms.

With you I will club with you horse and its rider,

With you I will club chariot and its charioteer.

With you I will club man and woman,

With you I will club old and young,

With you I will club lad and maiden.

With you I will club shepherd and his flock,

With you I will club farmer and his team,

With you I will club governors and prefects.

And I will repay Babel and all inhabitants of Chaldea all their evil which they did in Zion before your eyes - oracle of YHWH (v. 20-24).

The verbs are rendered in the future tense, but the preposition beth again has an instrumental value. ${ }^{19}$ The club oracle becomes a poem about the future wars of God, whose scope goes beyond the conflict with the historical capital of the Neo-Babylonian empire. ${ }^{20}$ This translation poses a new question and seeks an answer about what entity stands behind the club metaphor. The possible interpretations are numerous.

Compagnie 1936) 342; W. Rudolph, Jeremia (HAT 12; Tübingen: J.C.B. Mohr (Paul Siebeck) 1958) 287; J. Bright, Jeremiah. Introduction, Translation and Notes (AB 21; New York: Doubleday 1965) 356.

19 Such translations were proposed by: Keil, Commentary, 441; Ehrlich, Randglossen, 369.

20 Hoffman rightly argued for the universalistic and meta-historical interpretation of Jer 50-51.

Here Babylon is a type of evil empires and loses its connection with the geographical and historical reference to a particular city of the past; Hoffman, "Jeremiah 50-51", 23, 25. 


\section{a) Israel}

According to Jer 51:10 the people of God witnesses the vengeance on Babylon. And since in the next verse God addresses Babylon's enemies ("Sharpen the arrows!") some interpreters argued that Israel actively takes part in this battle. The same analogy could be applied to v. 24: as inhabitants of Jerusalem witnessed the destruction of Zion, they are now to watch the destruction of Babylon. William L. Holladay, like Heinrich Ewald before him, ${ }^{21}$ contended that the club mentioned in v. 20 should be identified with Israel. He remarked first that אֵת in v. 20 is singular masculine and therefore it does not correspond well to Babylon, which is construed as feminine (cf. v. 13-14). Although Israel played no real military role in the historical events of its own liberation, the very poem of Jer 50 suggests - he reasoned - the nation's gradual empowerment, since the exiles move from being "a perishing flock" in 50:6 to "he-goats at the head of the flock" in 50:8. Holladay suggests that at least some of the battle commands are in fact addressed to Israel and he is right that the interpretation of these lines has consequences for the understanding of all of Jer $50-51 .^{22}$

We may support Holladay's argument with the reading provided by the LXX, where the battle of YHWH is identified with the battle of his people: $\dot{\varepsilon} \kappa \delta$ ík

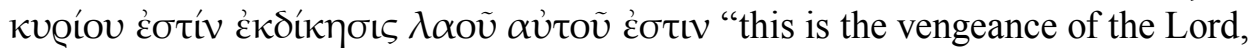
this is the vengeance of his people" $28: 11^{\mathrm{LXX}}\left(51: 11^{\mathrm{MT}}\right)$. This interpretation does not presume any actual or imaginary military triumphs of the $6^{\text {th }}$ century BC Judeans in Mesopotamia, of course. It is rather a theological appropriation of God's victory by his people: YHWH's triumph is their triumph.

If Babylon in Jer 50-51 is, as some scholars and the Biblical tradition understand it, a figure for any evil empire, its final fall has a universal character and cannot be limited to any single historical event. Historical Babylon was abandoned only in $126 \mathrm{BC}$, after the Parthian destruction. This means that for most of the Biblical period Babylon and its Judean community thrived. History itself suggests that the interpretation of Babylon in Jer 50-51 cannot be reduced to the historicising perspective of a datable event. The meaning of the club of God in this text goes beyond the eye-witnesses of a historical destruction of Zion or a historical destruction of Babylon. Kessler is right to see here a paraenesis directed to all faithful Jews. ${ }^{23}$

21 H. Ewald, Die Propheten des Alten Bundes. 3. Die Jüngsten Propheten des alten Bundes: Mit den Büchern Barukh und Daniel (Zweite Auflage) (Göttingen 1867) 153. Ewald treats Jer 50-51 separately from the Book of Jeremiah as a composition by an unknown prophet; ibid. 140-141.

22 W. Holladay, Jeremiah 2: A Commentary on the Book of the Prophet Jeremiah Chapters 26-52 (Hermeneia; Minneapolis: Fortress Press 1989) 405-407.

23 Kessler, Battle, 118. 


\section{b) "Something mythical"}

This enigmatic expression is a quote from Robert P. Carroll's commentary, in which, with good reason, he pointed to a very similar, parallel passage from the preceding chapter in Jer 50:35-38, where a poem, or rather a curse against the Chaldeans is pronounced ${ }^{24}$. Its main object is also a weapon, 'sword' חֶרֶב being repeated five times as an anaphora: “A sword upon!” Similar to our poem, different categories of the sword's victims are mentioned in order to express the range of its destructive power. The same pair "horses and chariots" is also found (cf. 50:37 and 51:21). Jer 50:25 leaves no doubt that the person waging the battle and handling this sword is no one else than YHWH alone:

YHWH has opened His storage

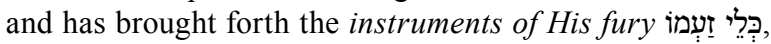

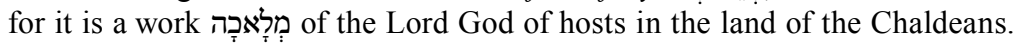

The parallels suggest that this image may well serve as an interpretative key to the Hammerspruch of the next chapter.

The fact that God addresses his own divine weapon is not surprising since a similar invocation occurred already in Jer 47:6 in the oracle against the Phi-

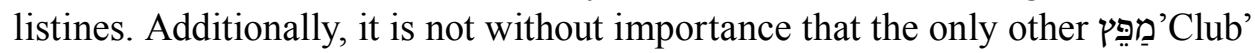
in the Hebrew Bible is found in Ezek 9:2 in the "Seven against Jerusalem" scene. Indeed the Seven Men described by Ezekiel function as seven personified instruments of divine wreath. ${ }^{25}$ Just as it is not necessary to identify the Seven from Ezek 9 with any earthly reality, so it is not necessary to do so for the 'Club' in Jer 51. Carroll may have the right intuition in naming this weapon "something mythical." Last but not least, God in the Book of Jeremiah has no problems comparing his own Word to a 'hammer' פַטִיש (Jer 23:29), although there a different term is used.

\section{c) Individual human beings}

The Talmudic Tradition gave names to the seven weapons of Ezekiel. ${ }^{26}$ Similarly, some modern exegetes try to identify the 'Club' from our poem with some

24 R.P. Carroll, Jeremiah (OTL; London: SCM Press 1986) 844.

25 The parallel to the Divine Seven from the Neo-Babylonian Poem of Erra is justified, although there is no need to claim any literary dependence; see: D. Bodi, The Book of Ezekiel and the Poem of Erra (OBO 104; Fribourg: Éditions universitaires de Fribourg: Vandenhoeck \& Ruprecht 1991) 99-110.

26 Bodi, The Book of Ezekiel, 98-99. 
particular historical figure. Ferdinand Hitzig argued that no one else but Cyrus could have been in the author's mind. ${ }^{27}$ Others wrote about an anonymous enemy of Babylon, analogous to the Enemy from the East in Isa 41:2, or the Enemy from the North in Isa 41:25. ${ }^{28}$

Jack Lundbom thought about Jeremiah himself as the Club of the Lord. ${ }^{29}$ Indeed, in the broader context of the whole book, it is Jeremiah who is sent to the nations with the mission of destruction $(1: 10,5: 14)$.

Jeremiah's Hammerspruch does not disclose the identity of God's instrument, but rather opens up a quest for the divine Club. It is even possible to associate Judah the Maccabee, i.e. Judah the Hammer, with Jeremiah's weapon. In a paradigmatic, or if one wishes, "mythological" manner, the author of 2 Macc seems to be inspired by the Book of Jeremiah. Behold the dream of Judah Maccabeus as narrated by himself in the last chapter of the book:

[...] There appeared a man with gray hairs, and distinguished in glory, who had something of a wonderful and majestic authority about him. Then Onias answered, saying, This is a lover of the brethren, who prays for the people and the holy city: Jeremiah, the prophet of God. Holding forth his right hand, Jeremiah gave to Judah a golden sword. While giving it he spoke thus: Take this holy sword, a gift from God, with the which thou will shatter

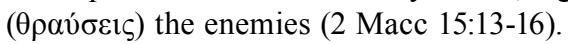

The golden sword is given to Judah by Jeremiah, the one who yielded the "hammer of the word" and was a divine instrument himself, "against the nations and the kingdoms," a weapon more effective than God's former hammer, Babylon. ${ }^{30}$

The poetic conclusion in Jer 51:24 does not end the process of interpretation but rather adds a renewed impetus for the re-readings. Possible identifications of God's club are thus numerous. Again, this imprecision, or rather this interpretative openness is not to be solved away but noted. Since the Book of Jeremiah is transmitted as a truly prophetic book, it does not intend to be just a set of poems about the past events. The reader is obliged to extract "tacit inferences from structurally ambiguous sentences"; this movement is able first to expose

27 F. Hitzig, Der Prophet Jeremia. Dritte Lieferung (KEHAT; Leipzig: Weidmann'sche Buchhandlung 1866) 405.

28 E.W. Nicholson, The Book of the Prophet Jeremiah. Chapters 26-52 (CBC; Cambridge: Cambridge University Press 1975) 216; T.E. Fretheim, Jeremiah (Smyth and Helwys Bible Commentary 15; Macon, GA: Smyth and Helwys 2002) 639.

29 J.R. Lundbom, Jeremiah: A Study in Ancient Hebrew Rhetoric (SBL.DS 18; Montana: Scholars Press 1975) 91. In his later AB commentary Lundbom hesitates about this identification; J.R. Lundbom, Jeremiah 37-52: A New Translation with Introduction and Commentary (AB 21C; New York: Doubleday 2004) 451-452.

30 The commentators of 2 Macc usually understand Jeremiah just as an intercessor; e.g.: R. Doran, 2 Maccabees: A Critical Commentary (Hermeneia; Minneapolis: Fortress Press 2012) 292. 
and second to shape the reader himself ${ }^{31}$. The imprecision of the Hammerspruch is not random; rather it forces us to keep the eyes wide open, seeking for God's club: both in the text and in history.

\section{Conclusions: Poetic "Faults"}

Biblical texts, like the earth's crust, have faults that give evidence of otherwise hidden movements. They are here for a reason, for it is exactly the aim of the interpretative loop to activate the readers' questioning. Limiting the interpretation to a single meaning would actually shut the door to understanding. A new perspective arises without obliterating the former perceptions. An unconscious weapon of the past, an object of future violence, a hammer or hammers of God serving throughout the whole of history - these are all different things; and yet the Hammerspruch suggests that a weapon can easily become a victim, or at least that these diverse states are easily confused in human eyes.

The ambiguity is something to be observed and followed, something that gives rise to the thought. The deep purpose of the Jeremian Hammerspruch is not essentially to provide a new set of data. This text is true poiesis; it does something to its reader, like an implicit inquisitive teacher: "Read again! Who is the winner and who is the looser? Is it about the past or about the future, or the present? Where does the victory or failure begin?" The habitus of rereading is also a virtue of exercising one's mind and this outcome is much more desirable than just impressing convictions onto a passive receiver. What is at stake is the reader's interpretative capacities, for the poem intends to shape a more attentive and flexible interpreter: a "re-reader" of the texts, and therefore also a "re-reader" of reality.

In the case of Jer 51:20-24 we are surprised with the shifts of our own interpretation simply because the shifts of time and identification of the implied figures differ so greatly. We experience in a very blatant way something that is probably true for any progress in understanding: interpretation usually means reinterpretation. In consequence, to read good literature must mean to re-read it.

\section{Bibliography}

Bodi, D., The Book of Ezekiel and the Poem of Erra (OBO 104; Fribourg: Éditions universitaires de Fribourg: Vandenhoeck \& Ruprecht 1991).

Bright, J., Jeremiah. Introduction, Translation and Notes (AB 21; New York: Doubleday 1965).

31 Walton, Fallacies, 93. 
Carroll, R.P., Jeremiah (OTL; London: SCM Press 1986).

Condamin, A., Le livre de Jérémie. Traduction et commentaire (troisième édition corrigée) (EB 14; Paris: Librairie Lecoffre: J. Gabalda et Compagnie 1936).

Doran, R., 2 Maccabees: A Critical Commentary (Hermeneia; Minneapolis: Fortress Press 2012). Ehrlich, A.B., Randglossen zur Hebräischen Bibel. 4. Jesaia, Jeremia (Leipzig: J.C. Hinrichs 1912).

Ewald, H., Die Propheten des Alten Bundes. 3. Die Jüngsten Propheten des alten Bundes. Mit den Büchern Barukh und Daniel (Zweite Auflage) (Göttingen: Vandenhoeck \& Ruprecht 1867).

Fischer, G., Jeremia 26-52 (HThKAT; Freiburg i.B.: Herder Verlag 2005).

Fretheim, T.E., Jeremiah (Smyth and Helwys Bible Commentary 15; Macon, GA: Smyth and Helwys 2002).

Hitzig, F., Der Prophet Jeremia. Dritte Lieferung (KEHAT; Leipzig: Weidmann'sche Buchhandlung 1866).

Hoffman, Y., "Jeremiah 50-51 and the Concept of Evil in the Hebrew Bible", The Problem of Evil and Its Symbols in Jewish and Christian Tradition (ed. H.G. Reventlow - Y. Hoffman) (JSOT.S 366; London: A\&C Black 2004) 14-28.

Holladay, W., Jeremiah 2: A Commentary on the Book of the Prophet Jeremiah Chapters 26-52 (Hermeneia; Minneapolis: Fortress Press 1989).

Joüon, P. - Muraoka, T., A Grammar of Biblical Hebrew (revised edition) (SubBib 27; Roma: Pontificio Istituto Biblico 2006).

Keil, C.F. - Delitzsch, F., Commentary in the Old Testament. 8. Jeremiah, Lamentations (originally in Edinburgh 1866-1891) (Peabody, MA: Hendrickson Publishers 2006).

Kessler, M., Battle of the Gods: The God of Israel versus Marduk of Babylon: A Literary/Theological Interpretation of Jeremiah 50-51 (SSN 42; Assen: Royal Van Gorcum 2003).

Lundbom, J.R., Jeremiah 37-52: A New Translation with Introduction and Commentary (AB 21C; New York: Doubleday 2004).

Lundbom, J.R., Jeremiah: A Study in Ancient Hebrew Rhetoric (SBL.DS 18) Montana: Scholars Press 1975).

McKane, W., Critical and Exegetical Commentary on Jeremiah. 2. Commentary on Jeremiah XXVI-LII (ICC; Edinburgh: T \& T Clark 1996).

Nicholson, E.W., The Book of the Prophet Jeremiah. Chapters 26-52 (CBC; Cambridge: Cambridge University Press 1975).

Plutarch, Moralia. 5 (transl. F. C. Babbitt) (Loeb Classical Library 306; Cambridge: Harvard University Press 1969).

Popko, Ł., "פי־שניםin 2 Kgs 2:13 as a Metaphor of Double Speech", RB, à paraître.

Roberts, J.J.M., "Does God Lie? Divine Deceit as a Theological Problem in Israelite Prophetic Literature", in: John A. Emerton (ed.), Congress Volume - Jerusalem 1986 (VT.S, 40; Leiden: Brill 1988) 211-220.

Rudolph, W., Jeremia (HAT 12; Tübingen: Mohr-Siebeck 1958).

Russell, D.A., Greek Declamation (Cambridge UK: Cambridge University Press 1983).

Volz, P., Der Prophet Jeremia (Zweite Aufl.) (KAT 10; Leipzig: A. Deichertsche Verlagsbuchhandlung D. Werner Scholl 1928).

Walton, D., Fallacies Arising from Ambiguity (Applied Logic Series 1; Springer Science \& Business Media 2013). 